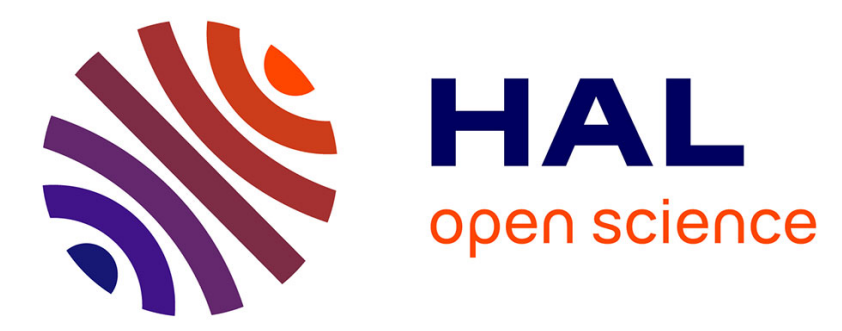

\title{
Estrogen Receptor Signaling is an Unstable Feature of the Gonadotropic L $\beta$ T2 Cell Line
}

Eertmans Frank, Dhooge Willem, de Wever Olivier, Wim Vanden Berghe, Bogaert Veerle, Bracke Marc, Haegeman Guy, Comhaire Frank, Kaufman Jean-Marc

\section{To cite this version:}

Eertmans Frank, Dhooge Willem, de Wever Olivier, Wim Vanden Berghe, Bogaert Veerle, et al.. Estrogen Receptor Signaling is an Unstable Feature of the Gonadotropic L $\beta$ T2 Cell Line. Molecular and Cellular Endocrinology, 2007, 273 (1-2), pp.16. 10.1016/j.mce.2007.04.009 . hal-00531922

\section{HAL Id: hal-00531922 \\ https://hal.science/hal-00531922}

Submitted on 4 Nov 2010

HAL is a multi-disciplinary open access archive for the deposit and dissemination of scientific research documents, whether they are published or not. The documents may come from teaching and research institutions in France or abroad, or from public or private research centers.
L'archive ouverte pluridisciplinaire HAL, est destinée au dépôt et à la diffusion de documents scientifiques de niveau recherche, publiés ou non, émanant des établissements d'enseignement et de recherche français ou étrangers, des laboratoires publics ou privés. 


\section{Accepted Manuscript}

Title: Estrogen Receptor Signaling is an Unstable Feature of the Gonadotropic L $\beta$ T2 Cell Line

Authors: Eertmans Frank, Dhooge Willem, De Wever Olivier, Wim Vanden Berghe, Bogaert Veerle, Bracke Marc, Haegeman Guy, Comhaire Frank, Kaufman Jean-Marc

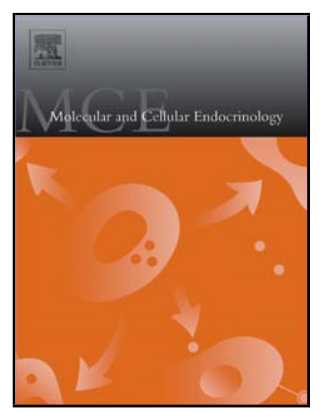

PII: S0303-7207(07)00162-1

DOI: doi:10.1016/j.mce.2007.04.009

Reference: MCE 6647

To appear in: $\quad$ Molecular and Cellular Endocrinology

Received date: $\quad 19-1-2007$

Revised date: 11-4-2007

Accepted date: $\quad$ 24-4-2007

Please cite this article as: Frank, E., Willem, D., Olivier, D.W., Berghe, W.V., Veerle, B., Marc, B., Guy, H., Frank, C., Jean-Marc, K., Estrogen Receptor Signaling is an Unstable Feature of the Gonadotropic L $\beta$ T2 Cell Line, Molecular and Cellular Endocrinology (2007), doi:10.1016/j.mce.2007.04.009

This is a PDF file of an unedited manuscript that has been accepted for publication. As a service to our customers we are providing this early version of the manuscript. The manuscript will undergo copyediting, typesetting, and review of the resulting proof before it is published in its final form. Please note that during the production process errors may be discovered which could affect the content, and all legal disclaimers that apply to the journal pertain. 


\section{Estrogen Receptor Signaling is an Unstable Feature of the Gonadotropic L $\beta$ T2 Cell Line}

Authors:
1. Eertmans Frank ${ }^{1}$
2. Dhooge Willem ${ }^{1}$
3. De Wever Olivier ${ }^{2}$
4. Wim Vanden Berghe ${ }^{3}$
5. Bogaert Veerle ${ }^{1}$
6. Bracke Marc $^{2}$
7. Haegeman Guy ${ }^{3}$
8. Comhaire Frank ${ }^{1}$
9. Kaufman Jean-Marc ${ }^{1}$

Address:

1. Department of Endocrinology, 6K12IE, Ghent University Hospital, De Pintelaan 185, B-9000 Ghent, Belgium

2. Laboratory of Experimental Cancerology, 1P7, Ghent University Hospital, De Pintelaan 185, B-9000 Ghent, Belgium

3. Department of Molecular Biology, Ghent University, K.L. Ledeganckstraat 35, B9000 Ghent, Belgium 
Corresponding author:

Frank Eertmans

Department of Endocrinology

6K12IE, Ghent University Hospital

De Pintelaan 185,

B-9000 Ghent, Belgium

Tel.: +3292403414

Fax; +3292403886

Running title:

Lack of estrogenic effects in gonadotropic L $\beta T 2$ cells

Key words:

Gonadotrophs, gonadotropin-releasing hormone, luteinizing hormone, 17- $\beta$-estradiol 


\section{Abstract}

The murine, gonadotropic $L \beta T 2$ cell line was assessed as a potential in vitro model to analyze estrogen receptor (ER)-mediated regulation of luteinizing hormone (LH) synthesis and secretion. In agreement with limited literature data, repeated exposure to (sub) physiological concentrations of gonadotropin-releasing hormone enhanced LH $\beta$ subunit gene expression, being the rate-limiting step of LH synthesis, and the corresponding LH secretory response. However, in the same subclone of the L $\beta T 2$ cell line, we observed that $\mathrm{LH}$ production was not affected following exposure to $E_{2}$, which is in contrast to previously reported weak or modest effects. One explanation may be the absence of measurable ERa protein expression on the one hand and impaired ER signal transduction on the other. Furthermore, an alternative ERa mRNA splicing variant was detected in the L $\beta T 2$ cell line, which (theoretically) encodes for a protein that may alter ERa transcriptional activity, depending on the cellular context.

The studied $L B T 2$ subclone did not show a generalized impairment of nuclear receptor function, as we observed androgen- and glucocorticoid-induced gene transcription, together with enhanced LH secretory response following dexamethasone treatment. Since its development, the gonadotropic $L \beta T 2$ cell line served as a reference model to study gonadotroph-specific effects because of its mature properties. Nevertheless, this cell line does not seem to be a suitable in vitro model for the study of estrogenic regulatory effects at the level of the pituitary gonadotrophs in view of the unstable nature of ER signaling in $L \beta T 2$ cells.

\section{Introduction}

Reproductive competence depends on the interplay between the different compartments 
of the hypothalamic-pituitary-gonadal axis. The episodic release of hypothalamic gonadotropin-releasing hormone $(\mathrm{GnRH})$ results in a pulsatile pattern of luteinizing hormone (LH) secretion by the pituitary gonadotrophs (Wildt et al., 1981). Luteinizing hormone is responsible for the synthesis and the release of gonadal steroids, which in turn alter gonadotropin secretion through feedback interactions at the level of the hypothalamus and the pituitary (Belchetz et al., 1978; Haisenleder et al., 1994; Bousfield, 2004). In males, both testosterone ( $\mathrm{T}$ ) and its aromatization product $17-\beta$ estradiol ( $\left.E_{2}\right)$ contribute to the regulation of LH secretion (Hayes et al., 2000; Tilbrook and Clarke, 2001). In females, E2 exerts a negative feedback on LH release for the greater part of the ovarian cycle, at least in part through direct actions at the pituitary level. This inhibitory action is transiently reversed into marked facilitation of pituitary LH secretion during the mid-cycle LH surge (Knobil, 1988; Herbison, 1998; Kerdelhué et al., 2002; Moenter et al., 2003)

The role of $\mathrm{E}_{2}$ in the $\mathrm{GnRH}$-mediated regulation of $\mathrm{LH}$ release by pituitary gonadotrophs has been extensively investigated using primary pituitary cell cultures and isolated perifused pituitaries (Emons et al., 1989; Ortmann et al., 1992a; Ortmann et al., 1992b) However, gonadotrophs represent only $10-15 \%$ of the anterior pituitary cell population (Wang, 1988) It has been established that paracrine interactions between gonadotrophs and other pituitary cell types, including lactotrophs and somatotrophs, may influence basal or GnRH-induced LH secretion (Cheung, 1983; Denef and Andries, 1983; Andries et al., 1995; Gregory et al., 2004), hereby complicating data interpretation. The need for in vitro models to study estrogenic effects at the pituitary level is further emphasized by the increasing interest for the therapeutic use of phytoestrogens and the development of selective estrogen receptor modulators on the one hand and growing concern for potentially disrupting effects of chemical pollutants with estrogenic actions on reproductive function on the other hand (Eertmans et al., 2003) 
The murine, gonadotropic L $\beta$ T2 cell line shows important similarities with mature gonadotrophs in vivo, including the expression of the $\mathrm{GnRH}$ receptor $(\mathrm{GnRH}-\mathrm{R})$ and the production of both gonadotropins $\mathrm{LH}$ and follicle stimulating hormone $(\mathrm{FSH})$ (Mellon et al., 1991; Alarid et al., 1996; Thomas et al., 1996; Graham et al., 1999) Therefore, this cell line is a useful in vitro model to unravel cellular mechanisms involved in LH synthesis and secretion and thus potentially also for the study of estrogen-specific regulation at the level of the pituitary gonadotrophs.

In the present study, LH secretion and the corresponding LH $\beta$-subunit (LH $\beta$-su) gene expression were assessed in the L $\beta T 2$ cells following exposure to $\mathrm{GnRH}$ alone or in combination with $\mathrm{E}_{2}$.

\section{Materials and Methods}

\section{Plasmids, chemicals and materials}

The reporter plasmid rLH $\beta$-Luc (Rosenberg and Mellon, 2002) was kindly provided by Dr. D. Coss (University of San Diego, La Jolla, CA, USA). The ERE-tk-Luc vector (Harnish et al., 2000) was a kind gift of Dr. W. Vanden Berghe (Ghent University, Ghent, Belgium). The pSG-hERa66 (HEGO) vector (Green et al., 1994), encoding for the human estrogen receptor a (hER $\alpha$ ) was a kind gift of Dr. J. A. Gustafsson (Karolinska Institute, Stockholm, Sweden). The MMTV-Luc reporter plasmid (De Vos et al., 1993) was kindly provided by Dr. F. Claessens (Faculty of Medicine, University of Leuven, Leuven, Belgium). The pSV- $\beta$-Gal vector, encoding for the enzyme $\beta$-galactosidase, was purchased from Promega (Leiden, The Netherlands). Gonadotropin-releasing hormone $(\mathrm{GnRH}), 17-\beta$-estradiol $\left(\mathrm{E}_{2}\right)$, dexamethaso ne (Dex) and primary antibodies against $\alpha-$ tubulin were obtained from Sigma (Bornem, Belgium). All cell culture products and Lipofectamine Plus were purchased from Invitrogen (Merelbeke, Belgium). The rat LH 
RIA, the anti-mouse and anti-rabbit secondary antibodies conjugated to horseradish peroxidase and ECL Western Blotting Detection Reagents were from Amersham Biosciences (Roosendaal, The Netherlands). RNAlater solution and the RNeasy mini-kit were purchased from Westburg (Leusden, The Netherlands). The Taqman PCR core reagent kit was obtained from Applied Biosystems (Lennik, Belgium). The RevertAid First Strand cDNA Synthesis Kit was from Fermentas (Sint Leon-Rot, Germany). PCR primers were purchased from Operon (Leiden, The Netherlands). Primary antibody against ERa (NCL-L-ER-6F11) was from Novocastra (Newcastle, United Kingdom).

\section{Cell culture}

The murine, gonadotropic $\alpha$ T3-1 and L $\beta T 2$ cell lines were kindly provided by $\mathrm{Dr}$. $\mathrm{P}$. Mellon (University of San Diego, La Jolla, CA, USA). The human cervical Hela cell line and the human breast cancer cell line MCF-7 (subclone AZ) were a gift from Dr. P. Briand (Jack Bell Research Center, British Columbia, Canada). Lung fibroblasts and pituitaries, isolated from C57BL/6 mice, were provided by Dr. K. Vermaelen (Ghent University Hospital, Ghent, Belgium). All cell lines were grown as a monolayer in a 5\% $\mathrm{CO}_{2}$, humidified atmosphere $\left(37^{\circ} \mathrm{C}\right)$ and weekly passaged in Dulbecco's Modified Eagle Medium (DMEM) containing 10\% fetal calf serum (FCS), 100 units/ ml penicillin G and $100 \mu \mathrm{g} / \mathrm{ml}$ streptomycin, except for the murine Sertoli TM4 cell line, which was grown in DMEM: Nutrient Mix F12 supplemented with 5\% horse serum, 2.5\% FCS, 100 units/ ml penicillin $\mathrm{G}$ and $100 \mu \mathrm{g} / \mathrm{ml}$ streptomycin.

\section{LH secretion studies}

L $\beta T 2$ cells $\left(5 \times 10^{5}\right.$ cells/ well) were seeded in 24 well plates and incubated for 48 hours, after which culture medium was replaced by phenol red-free DMEM: Nutrient Mix F12 supplemented with 5\% dextran-coated charcoal (DCC) treated FCS and antibiotics, containing $\mathrm{GnRH}(0.1-1000 \mathrm{nM})$, alone or in combination with $\mathrm{E}_{2}(0.2 \mathrm{nM})$ and Dex (20 
$\mathrm{nM})$, either alone or combined. Two stimulation setups were used whereby in a first approach, a 15 min exposure was followed by a 75 min collection period in $\mathrm{GnRH}$-free vehicle. In the second protocol, the cells were incubated continuously for several hours (1 h-6h). "Conditioned medium" was collected at the end of each incubation and stored at $-80^{\circ} \mathrm{C}$ until analysis. Cells were washed and incubated overnight in fresh steroid-free medium or medium containing one or both steroid hormones. Both stimulation protocols were repeated for the next two days. At day 5 (third day of stimulation), following medium collection, cells were counted and then stored at $-80^{\circ} \mathrm{C}$ in a mixture of $50 \mu \mathrm{L}$ of phosphate-buffered salines (PBS) and $250 \mu \mathrm{L}$ of RNAlater solution until total RNA extraction. For all experiments, experimental medium containing $0.1 \%$ ethanol, served as vehicle control, indicated by $\mathrm{C}$ in the figures. $\mathrm{LH}$ was measured using a commercial RIA (Amersham Biosciences, Roosendaal, The Netherlands) according to the manufacturer's protocol.

\section{RNA isolation, real time PCR analysis and reverse transcription PCR}

Total RNA was extracted from L $\beta$ T2 and TM4 cells, and from lung fibroblasts and total pituitaries, freshly isolated from C57BL/6 mice using the RNeasy mini-kit, treated with DNase and frozen at $-20^{\circ} \mathrm{C}$ until analysis.

Quantitative expression of LHß-subunit (LHß-su) messenger RNA (mRNA) with mouse $\beta$-actin as the internal standard was performed using the Taqman $®$ real-time analysis method on a Perkin-EImer ABI Prism 7700 sequence detection system (Applied Biosystems, Lennik, Belgium). A LHß-su-specific 120 bp fragment was amplified using forward primer (fp) 5'-CATCACCTTCACCACCAGCAT-3' and reverse primer (rp) 5'GAGGCGAAGCGCAGCTC-3', in combination with the TaqMan® probe 5'-FAMCCTCCCGTGCCTCAGCCAGTGT-TAMRA-3'. A mouse $\beta$-actin specific 138 bp fragment was amplified using fp, 5'-AGAGGGAAATCGTGCGTGAC-3' and rp, 5'- 
CAATAGTGATGACCTGGCCGT-3', in combination with Taqman® probe 5'-FAMCACTGCCGCATC CTCTTCCTCCC-TAMRA-3'. All primer/ probe sets were developed using the Primer Express software (Applied Biosystems, Lennik, Belgium), based on genbank entries NM_012858 (LHß-su) and NM_007393 ( $\beta$-actin). PCR conditions were as follows: a reverse transcription step at $48^{\circ} \mathrm{C}$ for $30 \mathrm{~min}$ and an initial denaturation step at $91^{\circ} \mathrm{C}$ for 10 minutes, followed by 40 cycles consisting of a denaturation step at $91^{\circ} \mathrm{C}$ for $1 \mathrm{~min}$, a $1 \mathrm{~min}$ annealing step at $65^{\circ} \mathrm{C}$ and a 2 min extension step at $72^{\circ} \mathrm{C}$. An elongation step of $10 \mathrm{~min}$ at $72^{\circ} \mathrm{C}$ finalized the amplification. LHß-su mRNA levels were quantified against a standard curve, prepared by a serial dilution (1/10) of $50 \mathrm{ng}$ total RNA extracted from $L \beta T 2$ cells; $\beta$-actin mRNA was quantified as a reference gene against a separate standard curve. Threshold cycle $\left(C_{T}\right)$ values for the $L H \beta$-su and $\beta$ actin were obtained for each sample, the corresponding dilutions were determined from both standard curves and the dilution ratio for LH $\beta$-su and $\beta$-actin was calculated. Values for treated cells are expressed relative to the control (untreated cells), set to $100 \%$.

For qualitative reverse transcription PCR analysis of the androgen receptor (AR), the glucocorticoid receptor (GR) and the ERa pituitary-specific variant truncated estrogen receptor product 1 (TERP-1), total RNA was reverse transcribed using the RevertAid First Strand cDNA Synthesis Kit, according to the manufacturer's instructions. The following PCR primers were used ( $f p=$ forward primer, $r p=$ reverse primer): a 203 bpspecific amplicon for AR fp, 5'-CTCTTCTTCCTGGCATACTCTCTT-3', AR rp 5'CTGGTGGAGTTGTGAACAGAGTAC-3', a 461 bp-specific amplicon for the GR fp, 5'GCCTGGTGTGCTCCGATGAA-3', GR rp, 5'-CACTGCGGCAATCACTTGGC-3',a 370 bp-specific amplicon for TERP-1, TERP-1 fp, 5'-CCATTTCTTGAGCTTGTTGAACAG-3', TERP-1 rp, 5'-GTGTCTGTGATCTTGTCCAGGAC-3' (adapted from Schreihofer et al., 2000) and a 238 bp-specific amplicon for $\beta$-actin fp, 5'-CTGGCACCACACCTTCTA-3', $\beta$ - 
actin rp, 5'-GGGCACAGTGTGGGTGAC-3'. Primers were based on genbank entries NM_013476, NM_008173, NM_007956 and NM_007393 for AR, GR, ERa respectively $\beta$-actin. Two microlitres of cDNA were amplified as follows: an initial denaturation step at $92^{\circ} \mathrm{C}$ for 10 min was followed by 40 cycles consisting of a denaturation step at $92^{\circ} \mathrm{C}$ for $30 \mathrm{sec}$, a $30 \mathrm{sec}$ annealing step $\left(58^{\circ}\right)$ and a $45 \mathrm{sec}$ extension step at $72^{\circ} \mathrm{C}$. An elongation step of $10 \mathrm{~min}$ at $72^{\circ} \mathrm{C}$ finalized the amplification. PCR products were analyzed using a $2 \%$ agarose gel electrophoresis, followed by ethidium bromide staining.

Expression of full length ERa and possible ERa mRNA splicing variants was analyzed using two primer sets. The first primer set was taken from Swope et al. (2002) and consists of a common FP and two different RPs, which are able to distinguish between full length ERa (516 bp) and a variant message (480 bp). Following RT-PCR analysis and agarose gel electrophoresis, densitometric analysis was performed using Digimizer image analysis software (Medcalc Software, Mariakerke, Belgium) to quantify full length ERa and the variant messages. The ratio of full length ERa to the variant message was calculated for each tested cell line and corrected for $\beta$-actin, which was amplified in parallel and served as a control for PCR efficiency on the one hand and as loading control on the other. The murine, gonadotropic $\alpha$ T3-1 cell line and the murine TM4 Sertoli cell line served as a positive control, while mouse lung fibroblasts served as an alleged negative control.

The second primer set (fp, 5'- GTCTGGTCCTGCGAAGGCTGC-3' and rp 5'TGACGTAGCCAGCAACATGTCAAAG-3'), adapted from the one described by Pasqualini and colleagues (1999) in the rat, yields an amplicon of 702 bp for full length ERa, while alternative splicing messages correspond to an amplicon of 585 bp (exon 4 deletion), 366 bp (exon 5 deletion) and 249 bp (exon 4 and 5 deletion), respectively. PCR conditions were similar to the conditions described above, differing only in 
annealing temperature of the reverse primer $\left(55^{\circ} \mathrm{C}\right.$ instead of $\left.45^{\circ} \mathrm{C}\right)$.

\section{Western Blot}

Lysates were prepared of MCF-7 cells (untransfected) and of L $\beta$ T2 and Hela cells, prior to and following transfection with a human estrogen receptor $\alpha(\mathrm{hER} \alpha)$ expression vector (50 ng). Cells were washed twice with PBS and lysed in Laemmli buffer (0.25 M Tris, $1.92 \mathrm{M}$ glycine and $1 \%$ sodium dodecyl sulphate in aqueous solution). Lysates were centrifuged at $14000 \mathrm{rpm}$ for $30 \mathrm{~min}$ at $4^{\circ} \mathrm{C}$, and protein concentration was determined by Lowry assay. All samples were diluted with sample buffer $(62 \mathrm{mM}$ Tris- $\mathrm{HCl}, \mathrm{pH} 6.8$, $10 \%$ glycerol, $5.0 \% \beta$-mercaptoethanol, 2.0\% SDS, 0.0012\% bromophenol blue) and heated at $94{ }^{\circ} \mathrm{C}$ for $5 \mathrm{~min}$. A total of $25 \mu \mathrm{g}$ of protein was loaded for each sample. Electrophoresis was carried out on a $10 \%$ separating gel at $100 \mathrm{~V}$ for $1 \mathrm{~h}$ in a MiniProtean II electrophoresis system (BioRad). After electrophoresis, proteins were transferred from polyacrylamide gels onto nitrocellulose membranes by electroblotting (0.8 $\mathrm{mA} / \mathrm{cm}^{2}$ constant current, $60 \mathrm{~min}$, room temperature). Following transfer, membranes were blocked with $5.0 \%$ dehydrated nonfat milk in TBS-T (20 mM Tris- $\mathrm{HCl}$, $\mathrm{pH} 7.4,137 \mathrm{mM} \mathrm{NaCl}, 0.10 \%$ Tween-20) for $60 \mathrm{~min}$ at room temperature. Membranes were then washed three times in fresh TBS-T followed by a $1 \mathrm{~h}$ incubation with primary antibody. Following washing (3x TBS-T, $5 \mathrm{~min}$ ), membranes were incubated for $1 \mathrm{~h}$ in secondary antibody. Immunodetection was performed with an enhanced chemiluminescence (ECL) system according to manufacturer's specifications. Chemiluminescence was captured on photographic film. Each Western blot was exposed for $15 \mathrm{~s}, 30 \mathrm{~s}$ and $60 \mathrm{~s}$ to guarantee linearity of the film.

\section{Transient transfection studies}

Cells were grown in 24-well plates at a density of $1.25 \times 10^{5}$ cells per well (L $\beta$ T2 cell line) respectively $3 \times 10^{4}$ cells per well (Hela and TM4 cell lines) in identical conditions as for 
the secretion experiments. Following overnight incubation, cells were transfected with rLHß-Luc (250 ng) or MMTV-Luc (50 ng) using Lipofectamine Plus according to the instructions of the manufacturer. The ERE-TK-Luc (250 ng) reporter plasmid was transfected in L $\beta T 2$ cells, alone or in combination with the HEO expression vector, encoding for the hERa (50 ng). In each experiment, a reporter plasmid, encoding for the enzyme $\beta$-galactosidase ( $\beta$-gal; 20ng) was co-transfected in order to control for transfection efficiency. Twenty-four hours later, cells were treated for $16 \mathrm{~h}$ with test compounds. After cell lysis, luciferase and $\beta$-gal activities were determined using a Packard Lumicount Microplate luminometer (Packard Instrument Company Inc., Meriden, CT, USA). Luciferase values were normalized for $\beta$-gal values and the obtained results for treated cells were expressed relative to the control (untreated cells), set to $100 \%$

\section{Statistical analysis}

Values in the figures are presented as the average \pm SD. Curve analysis (four parameter logistic regression) was performed using Sigmaplot 8.0 (SPSS Inc., Chicago, USA). Statistical analysis was carried out by oneway ANOVA using the SPSS 11 statistical package (SPSS Inc., Chicago, USA). Significant differences were determined by the Dunnet's post hoc test; statistical significance was inferred at $P<0.05$.

\section{Results}

\section{LH secretion and LH $\beta$-subunit (LH $\beta$-su) gene expression following GnRH challenge}

A short pulse setup was applied to investigate the LH secretory response of L $\beta T 2$ cells following repeated $\mathrm{GnRH}$ treatment. $L \beta T 2$ cells were exposed to $15 \mathrm{~min} G \mathrm{nRH}$, followed by a 75 min collection of $\mathrm{GnRH}$-free medium. On the first treatment day, LH secretion, as measured by RIA, was not induced by raising concentrations of $\mathrm{GnRH}(0.1-1000 \mathrm{nM})$. 
On treatment day 2 , LH release was significantly induced, reaching a plateau at $10 \mathrm{nM}$ of $\mathrm{GnRH}$. At day 3, maximal induction of secretion was shown at $10 \mathrm{nM}$ of $\mathrm{GnRH}$ followed by a declining $\mathrm{LH}$ response at higher $\mathrm{GnRH}$ concentrations, the secretion at 1 $\mu \mathrm{M}$ being no longer different from the blank. When investigating the effect of varying the duration of $\mathrm{GnRH}$ exposure from $1 \mathrm{~h}$ up to $6 \mathrm{~h}$, stimulation for $4 \mathrm{~h}$ was found to result in the largest difference between stimulated and unstimulated cells. Despite the fact that LH medium concentrations were approximately 1.55 fold higher for cells treated with $\mathrm{GnRH}$ for $4 \mathrm{~h}$ in comparison to L $\beta T 2$ cells exposed for $15 \mathrm{~min}$, no differences were observed in the LH release profile between both stimulation setups (Fig. 1A and 1B). In a next series of experiments, the short pulse setup was used to investigate the effects of $E_{2}(0.2 n M)$ and Dex $(20 \mathrm{nM})$ on $\mathrm{LH}$ secretion as assessed on the third day of repeated exposure to $\mathrm{GnRH}$. 17- $\beta$-estradiol alone did not alter cell number or the $\mathrm{LH}$ secretory response. In contrast, a significant $(P<0.001)$ decrease of $20 \%$ in cell number was observed in Dex-exposed L $\beta$ T2 cells, with a significant $(P=0.002)$ increase in LH release, corrected for cell number, when compared to cells exposed to $\mathrm{GnRH}$ (10 nM) alone. We observed a comparable $19 \%$ reduction in cell number (fig. 2) and a borderline significant $(P=0.06)$ induction of LH secretion, corrected for cell number, in L $\beta T 2$ cells, treated with both $E_{2}$ and Dex, in comparison to cells treated with $\mathrm{GnRH}(10 \mathrm{nM})$ alone. Results are shown in figure 3.

LH $\beta$-subunit (LH $\beta$-su) messenger RNA (mRNA) expression, as determined using realtime PCR, was significantly $(P<0.05)$ induced by $\mathrm{GnRH}$ in a dose-dependent manner; at $1 \mu \mathrm{M}$ of $\mathrm{GnRH}, \mathrm{mRNA}$ levels were approximately 3 fold higher compared to the control. In the presence of $E_{2}$ and Dex, LHß-su mRNA levels remained unchanged in comparison to cells treated with $\mathrm{GnRH}$ alone (Fig. 4). The expression of mouse $\beta$-actin mRNA, which served as an internal standard, was not affected by any treatment (data 
not shown).

Finally, LHß-su promoter activity was studied following treatment with $\mathrm{GnRH}$ using the reporter plasmid rLHß-Luc. Luciferase activity was dose-dependently induced by $\mathrm{GnRH}$, while co-incubation with $\mathrm{E}_{2}$ and Dex did not affect promoter functioning (Fig. 5).

\section{Gonadotropin subunits and hormone receptor expression}

Expression of the mRNAs encoding for the $\mathrm{GnRH}$-receptor and the gonadotropin

subunits was demonstrated in our subclone of the $L \beta T 2$ cell line and in C57BL/6 mouse pituitaries, serving as a positive control (data not shown).

Expression of full length ERa and possible ERa mRNA splicing variants was analyzed in Lßß2 cells using different primer sets. The first primer set distinguishes between full length ERa (516 bp) and a variant message (482 bp), which results from inappropriate splicing at the 3'-end of exon 4. The levels of full length ERa were 1.6-fold higher in comparison to the variant message. In contrast, the ratio of full length ERa to the variant message was significantly $(P<0.05)$ higher $(3.7-$ and 3.5 -fold, respectively) in the murine, gonadotropic, aT3-1 cell line and in the murine, TM4 Sertoli cell lines, both serving as a positive control. No bands could be detected in the mouse, lung fibroblast. An example of a representative gel electrophoresis is illustrated in figure $6 \mathrm{~A}$.

In a second series of experiments, a primer set was used which is able to detect both full length ERa mRNA and splicing variants, which result from deletion of exon 4, exon 5 or the combination of both exons. Following RT-PCR analysis, only full length ERa was amplified, while no splicing variants could be detected in the L $\beta T 2$ cell line. Observations were identical in the $\alpha \mathrm{T} 3-1$ and TM4 cell lines, showing higher expression of full length ER $\alpha$ mRNA when compared to the L $\beta T 2$ cells (Fig. 6B). Furthermore, we were unable to demonstrate expression of the pituitary-specific truncated estrogen receptor product-1 (TERP-1) in the L $\beta T 2$ cell line, while positive results were obtained using C57BL/6 mouse pituitaries (data not shown). 
Following Western analysis, neither ERa protein (Fig. 6) nor the (theoretically) expected protein of $42.3 \mathrm{kDa}$ could be detected. Similar negative results were obtained for the demonstration of full length ERa $(66 \mathrm{kDa})$ in LßT2 cells which were grown in DMEM containing varying concentrations (1-10\%) of either non-treated or DCC-treated FCS, respectively (data not shown).

Transfection with an expression vector, encoding for the human ERa (HEO), strongly induced receptor expression. Lysates from human MCF-7 breast cancer cells and from human cervical Hela cells, transfected with the HEO expression vector, served as a positive control (Fig. 7). In contrast to the low ERa mRNA abundance, the glucocorticoid receptor (GR) and the androgen receptor (AR) were strongly expressed in the L $\beta T 2$ cell line. For all amplicons of interest, all primer sets yielded negative results when applied to mouse fibroblast mRNA which served as an alleged negative control. Mouse $\beta$-actin expression was used to control for PCR efficiency (data not shown).

\section{Assessment of hormone receptor-mediated gene expression}

No response could be observed in L $\beta T 2$ cells, transiently transfected with an ER-driven reporter construct (ERE-TK-Luc), following exposure to $E_{2}(16 h ; 10 p M-1 \mu M)$. In addition, L $\beta$ T2 cells did not respond to $E_{2}$ following co-transfection with an expression vector encoding for the human ERa. As a positive control, the human Hela cell line was transfected in parallel. $E_{2}$ was able to stimulate luciferase activity in a dose-dependent manner, with an EC50 of $1.68 \mathrm{pM}$. At the highest concentration of $\mathrm{E}_{2}(10 \mathrm{nM})$ tested, ERmediated luciferase induction was 22.55 -fold in comparison to vehicle control. Results are presented in figure 8.

AR- and GR-mediated gene transcription was investigated in L $\beta T 2$ cells using a MMTVLuc reporter construct. At a concentration of $1 \mu \mathrm{M}$, MMTV promoter activity was significantly $(P<0.05)$ stimulated by dihydrotestosterone $(\mathrm{DHT})$ and Dex $(1.83$ fold and 
2.5 fold, respectively, in comparison to vehicle control) in the L $\beta T 2$ cell line. As a positive control, the mouse Sertoli TM4 cell line was transfected in parallel. Luciferase activity showed a significant $(P<0.05) 2.21$ fold and 4.56 fold increase when compared to vehicle control following treatment with DHT and Dex respectively. Results are shown in fig. 9 .

\section{Discussion}

Whereas the results of the present study confirm that the murine, gonadotropic L $\beta T 2$ cell line displays characteristics of mature gonadotrophs in vivo with gonadotropin-releasing hormone $(\mathrm{GnRH})$ inducible luteinizing hormone $(\mathrm{LH})$ secretion, in our hands, extensive experiments failed to demonstrate regulatory effects of 17- $\beta$-estradiol $\left(E_{2}\right)$.

Using a short pulse setup, daily repeated exposure to (sub) physiological concentrations of $\mathrm{GnRH}$ enhanced $\mathrm{LH}$ release by $\mathrm{L} \beta T 2$ cells, except on the first treatment day, showing lack of secretory response following $\mathrm{GnRH}$ challenge. These findings suggest that the previously well documented self-priming effect of GnRH (Aiyer et al., 1974; Waring and Turgeon, 1980) was preserved in the L $\beta T 2$ cell line. Turgeon et al. (1996) and Nicol et al., (2002) also reported increased responsiveness of L $\beta$ T2 cells, although there was already a significant response on day 1 . In our experiment, increasing the exposure time to $4 \mathrm{~h}$, although resulting in higher basal medium $\mathrm{LH}$ concentrations, still failed to show a significant response to $\mathrm{GnRH}$ challenge on day 1 . In addition, the $\mathrm{LH}$ secretion pattern in response to $\mathrm{GnRH}$, seen on the following treatment days was identical for the short and longer stimulation setups.

On the third day of exposure, we observed a maximal effect at $10 \mathrm{nM}$ of $\mathrm{GnRH}$, while higher concentrations resulted in a decreased secretory response, which is in agreement with the findings of Nicol (Nicol et al., 2002). Currently, the mechanism underlying the latter phenomenon remains unknown, but post-transcriptional processes or vesicle 
storage of LH may be impaired in the L $\beta$ T2 cell line at these supraphysiological $\mathrm{GnRH}$ concentrations. Indeed, in our experiments, a diminished response to higher GnRH concentrations was not seen for LH $\beta$-subunit (LH $\beta$-su) promoter activity and the corresponding messenger RNA (mRNA) expression, which were both dose-dependently stimulated by $\mathrm{GnRH}$, hereby reaching a maximal effect at $1 \mu \mathrm{M}$.

On the third day of repeated exposure to $10 \mathrm{nM}$ of $\mathrm{GnRH}$, we did not observe any changes in cell number and the LH secretory response of L $\beta T 2$ cells in the presence of $\mathrm{E}_{2}$. In contrast, dexamethasone (Dex) treatment decreased cell number while stimulating the LH secretory response. Results for the combination of both steroids were similar as for Dex alone. Turgeon and colleagues reported that a significant effect of $E_{2}$ was seen only on the fourth day of repeated exposure. Furthermore, in their experiments, the $\mathrm{GnRH}$-induced secretory response to Dex was approximately 2-fold higher in comparison to the $E_{2}$-treated group and was comparable to the effects they observed in $E_{2^{-}}$and Dex-treated ( $E_{2} /$ Dex) cells (Turgeon et al., 1996). In contrast, at day 3 of repeated exposure, Nicol and colleagues reported that LH secretion was significantly stimulated by all steroid treatments, with a stronger induction in the Dex-group in comparison to $E_{2}$-treated cells (Nicol et al., 2002). Similar to the observations of Turgeon (1996) the combination of both steroids had no additional effects above the Dexmediated response.

In our hands, the combination of $E_{2}$ and Dex did not influence $\mathrm{GnRH}$-induced LHß-su gene expression, being the rate-limiting step of LH synthesis (Evans, 1999; Yamada et al., 2004). Our data are in agreement with the findings of Turgeon (1996), but are at variance with the observations of Nicol (2002), showing inconsistent effects on LH $\beta$-su mRNA expression. The lack of estrogenic response in our L $\beta T 2$ cell line may plausibly be attributed to the rather weak abundance of the mRNA encoding for the ERa and the absence of demonstrable receptor protein. Similar findings were reported by the gro up of 
Niswender (2003), who transfected ERa in the L $\beta$ T2 cell line because of the absence of the receptor (Colorado AES Projects COL00220; ref. 32)

Our data are conflicting with the observations of another group, reporting strong ERa mRNA and protein expression in the L $\beta$ T2 cells (Schreihofer et al., 2000). In our hands, different culture conditions did not affect ERa mRNA and protein expression.

Furthermore, we demonstrated that our L $\beta T 2$ cell line preserved the main properties of mature gonadotrophs in vivo, including mRNA expression of the $\mathrm{GnRH}$ receptor $(\mathrm{GnRH}$ $\mathrm{R}$ ) and the gonadotropin subunits, which is in agreement with other reports (Turgeon et al., 1996; Lawson et al., 2001). L $\beta$ T2 cells also showed a strong expression of the mRNAs encoding for the androgen receptor (AR) and the glucocorticoid receptor (GR). Dedifferentiation in function of time and passage number may be a possible explanation for the loss of ER expression in our subclone. This phenomenon was reported by Kim and colleagues (Kim et al., 2000) in immortalized hepatocytes, which were generated using simian virus 40 (SV40) T-antigen oncogenesis. The authors demonstrated that dedifferentiation was caused by chromosomal damages, induced by raising T-antigen levels following continuous passages. As SV40 T-antigen oncogenesis was used to develop the L $\beta$ T2 cell line (Alarid et al., 1996), we cannot exclude that similar effects occurred in these cells, resulting in the loss of cell characteristics, including ERa expression. Another explanation could have been overexpression of the truncated estrogen receptor product 1 (TERP-1) in our cell line. This pituitary-specific ER-isoform is able to modulate $\mathrm{E}_{2}$-mediated gene transcription, depending on the ER over TERP-1 concentration ratio (Resnick et al., 2000). However, TERP-1 expression appeared to be also absent in our L $\beta$ T2 cell line. Furthermore, another group reported that TERP-1 expression in the L $\beta$ T2 cells was considerably lower when compared to ERa and also varied between experiments (Schreihofer et al., 2000). 
Although we were not able to demonstrate TERP-1 expression in the L $\beta$ T2 cell line, we did show the expression of an alternative ERa mRNA, which results from inappropriate splicing at the $3^{\prime}$-end of exon 4 , whereby an intronic sequence is incorporated at this $3^{\prime}-$ end and downstream exons are deleted. Theoretically, this mRNA variant encodes for a protein of $42.4 \mathrm{kDa}$, which lacks most of the ERa ligand binding domain (LBD) (Swope et al., 2002). In the mouse, the exact function of this protein remains currently unknown $\underline{\text { but a similar variant has already been described in humans, where it was able to }}$ $\underline{\text { enhance or inhibit full length ERa transcriptional activity, depending on the cellular }}$ context (Bollig et al., 2000). Although we were not able to demonstrate the expression of this truncated protein in the L $\beta$ T2 cell line with the applied primary antibody, one can postulate that the observed lack of estrogenic effects in the $L \beta$ T2 cell line might be related to the low ratio of full length ERa to the variant message. These findings are in contrast to our observations in the gonadotropic a T3-1 and TM4 Sertoli cell lines, which are both estrogen-responsive. In the latter cell lines, substantially higher levels (3.7- and 3.5-fold) of full length ERa in comparison to the variant message were measured.

$\underline{\text { In the rat, Pasqualini and colleagues (2001) have described ERa splicing variants }}$ showing deletions of exon 3 and/ or exon 4, which can alter ER transcriptional activity 
either positively or negatively. Furthermore, these variant mRNAs were expressed in a $\underline{\text { stage- and region-specific manner (Pasqualini et al., 1999) in the presence of full length }}$ ERa mRNA. We have analyzed the expression of corresponding ERa splicing variants in the $L \beta$ T2 cell line. One important difference is the fact that the rat ERa gene contains only 8 exons, which is in contrast to the mouse gene, which consists of 9 $\underline{\text { exons. In other words, the murine ERa gene exons } 4 \text { and } 5 \text { correspond to rat exons } 3}$ and 4. We have performed RT-PCR analysis using a primer set which was derived from the one described by Pasqualini and colleagues (1999). However, no ERa splicing variants were detected in the L $\beta$ T2 cell line nor in the other two tested murine cell lines $\underline{\text { (a T3-1 and TM4 cell line) }}$

In order to by-pass the apparent absence of ERa protein, L $\beta$ T2 cells were transiently transfected with an expression vector encoding for the human ERa in combination with an ER-driven reporter construct (ERE-tk-Luc). Despite strong expression of ERa protein, as demonstrated using Western blot analysis, $E_{2}$ treatment still failed to stimulate estrogen response element (ERE)-mediated luciferase expression. In contrast, Dex and dihydrotestosterone (DHT) were able to stimulate the mouse mammary tumor virus (MMTV) promoter, which is under transcriptional control of the GR and the AR. 
These observations, together with the demonstrated mRNA expression of both receptors, suggest a specific problem of ER signaling in the L $\beta$ T2 cell line, rather than a generalized impairment of nuclear receptor functioning.

It should be noticed that we transfected human ERa into a murine cell line, and thus that a species-specific incompatibility might underlie our negative transfection results in the L $\beta$ T2 cell line. However, similar experiments were performed in the mouse TM4 Sertoli cell line, whereby transfection with a HEO vector and ERE-LUC resulted in a significant increase in estrogenic response above cells, transfected with ERE-Luc alone (data not shown).

Recently, Turgeon and Waring (2006) demonstrated that progesterone receptor (PR) A and $B$ expression in $L \beta T 2$ cells was not affected by $E_{2}$, which was in contrast to their observations in rat and mouse pituitary cultures, showing increased expression of both $\mathrm{PR}$ isoforms following $\mathrm{E}_{2}$-exposure. Another group reported a decrease in $\mathrm{GnRH}$ induced aromatase promoter activity in L $\beta T 2$ cells treated with $\mathrm{E}_{2}$ (Galmiche et al., 2006), however at a 50.000-fold higher concentration (10 $\mu \mathrm{M})$ in comparison to our and other experiments (Turgeon et al., 1996; Nicol et al., 2002).

The present results indicate the importance of careful analysis of data, obtained in highly specific cell lines. In the case of the L $\beta$ T2 cell line, the previously reported estrogenic effects were rather modest or weak (Turgeon et al., 1996; Nicol et al., 2002) Moreover, variable outcome may occasionally be observed even for cell lines yielding much more robust estrogenic responses than those previously described for L $\beta T 2$ cells, such as in 
the human MCF-7 breast cancer cell line, which has been widely used in validated in vitro assays to assess estrogenic effects (Rasmussen and Nielsen, 2002). One can postulate that ER-mediated signaling is an unstable feature of the L $\beta T 2$ cell line, which is vulnerable to dedifferentiation

In conclusion, in our hands, extensive investigations failed to demonstrate any regulatory effect of $E_{2}$ on the $\mathrm{GnRH}$-induced LH secretory response and the corresponding $\mathrm{LH} \beta$-su gene expression in the L $\beta T 2$ cell line. Underlying causes appear to be situated at different levels involved in ER signal transduction, including rather weak ERa mRNA expression, the absence of a functional ERa protein and lack of estrogenic response following co-transfection with an ERa expression vector. Furthermore, the relative strong expression of an ERa mRNA splicing variant in comparison to full length ERa mRNA suggests a possible role for this variant in abnormal ER signaling in the L $\beta T 2$ cell line. In view of the inconsistencies between laboratories or subclones in the expression of ERmediated signaling, the L $\beta$ T2 cell line does not seem to be a suitable in vitro model for the study of estrogen regulation of gonadotropin synthesis and secretion. It seems relevant to point out this limitation in view of the unique position of the L $\beta T 2$ cell line as an immortalized cell line reflecting essential properties of mature gonadotrophs and a well established and useful model for in vitro studies of gonadotropin regulation.

\section{Acknowledgements}

The authors would like to thank Kathelijne Mertens and Sabrina Stuyvaert for the excellent technical assistance.

\section{Funds}

F. Eertmans is a PhD student and O. De Wever is a postdoctoral researcher, funded by Bijzonder Onderzoeksfonds (BOF) of the Ghent University.

\section{References}


1. Aiyer M. S., Chiappa S. A. and Fink G. (1974) A priming effect of luteinizing hormone releasing factor on the anterior pituitary gland in the female rat. J. Endocrinol. 62, 573-588.

2. Alarid E. T., Windle J. J., Whyte D. B. and Mellon P. L. (1996) Immortalization of pituitary cells at discrete stages of development by directed oncogenesis in transgenic mice. Development 122, 3319-3329.

3. Andries M., Vande Vijver V., Tilemans D., Bert C. and Denef C. (1995) Interaction of alpha T3-1 cells with lactotropes and somatotropes of normal pituitary in vitro. Neuroendocrinology 61, 326-336.

4. Belchetz P. E., Plant T. M., Nakai Y., Keogh E. J. and Knobil E. (1978) Hypophysial responses to continuous and intermittent delivery of hypopthalamic gonadotropin-releasing hormone. Science 202, 631-633.

5. Bollig A. and Miksicek R. J. (2000) A. Bollig An estrogen receptor-alpha splicing variant mediates both positive and negative effects on gene transcription. Mol. Endocrinol. 14 (2000), pp. 634-649.

6. Bousfield G. R., Perry W. M. and Ward D. N. (1994) Gonadotropins: chemistry and biosynthesis, in The Physiology of Reproduction, vol. 1, E. Knobil, ed., Raven Press, New York, pp. 1749-1792.

7. Cheung C. Y. (1983) Prolactin suppresses luteinizing hormone secretion and pituitary responsiveness to luteinizing hormone-releasing hormone by a direct action at the anterior pituitary. Endocrinology 113, 632-638.

8. Chrousos G. P. (1999) A new "new" syndrome in the new world: is multiple postreceptor steroid hormone resistance due to a coregulator defect? J. Clin. Endocrinol. Metab. 84, 4450-4453.

9. De Vos P., Claessens F., Peeters B., Rombauts W., Heyns W. and Verhoeven G. (1993) Interaction of androgen and glucocorticoid receptor DNA-binding 
domains with their response elements. Mol. Cell. Endocrinol. 90, R11-16.

10. Denef C. and Andries M. (1983). Evidence for paracrine interaction between gonadotrophs and lactotrophs in pituitary cell aggregates. Endocrinology 112, 813-822.

11. Eertmans F., Dhooge W., Stuyvaert S. and Comhaire F. 2003. Endocrine disruptors: effects on male fertility and screening tools for their assessment. Toxicol. In Vitro 17, 515-524.

12. Emons G., Frevert E. U., Ortmann O., Fingscheidt U., Sturm R., Kiesel L. and Knuppen R. (1989) Studies on the subcellular mechanisms mediating the negative estradiol effect on $\mathrm{GnRH}$-induced $\mathrm{LH}$-release by rat pituitary cells in culture. Acta Endocrinol (Copenh) 121, 350-360.

13. Evans J. J. (1999) Modulation of gonadotropin levels by peptides acting at the anterior pituitary gland. Endocr. Rev. 20, 46-67.

14. Galmiche G., Richard N., Corvaisier S. and Kottler M-L. (2006) The Expression of Aromatase in Gonadotropes Is Regulated by Estradiol and GonadotropinReleasing Hormone in a Manner that Differs from the Regulation of Luteinizing Hormone. Endocrinology 147, 4234-4244.

15. Graham K. E., Nusser K. D. and Low M. J. (1999) LbetaT2 gonadotroph cells secrete follicle stimulating hormone $(\mathrm{FSH})$ in response to active $\mathrm{A}$. J. Endocrinol. 162, R1-5. 
16. Green S., Walter P., Kumar V., Krust A., Bornert J. M., Argos P. and Chambon P., (1986) Human oestrogen receptor cDNA: sequence, expression and homology to v-erb-A. Nature 320, 134-139.

17. Gregory S. J., Townsend J., McNeilly A. S. and Tortonese D. J. (2004) Effects of prolactin on the luteinizing hormone response to gonadotropin- releasing hormone in primary pituitary cell cultures during the ovine annual reproductive cycle. Biol. Reprod. 70, 1299-1305.

18. Haisenleder D. J., Dalkin A. C., Marshall J. C., Knobil E. and Neill J.D. (1994) Regulation of gonadotropin secretion, in The Physiology of Reproduction, vol. 1, E. Knobil, ed., Raven Press, New York, pp.1793-1813.

19. Harnish D. C., Scicchitano M. S., Adelman S. J., Lyttle C. R. and Karathanasis S.K. (2000) The role of CBP in estrogen receptor cross-talk with nuclear factorkappaB in HepG2 cells. Endocrinology 141, 3403-3411.

20. Hayes F. J., Seminara S. B., Decruz S., Boepple P. A. and Crowley W. F. Jr. (2000) Aromatase inhibition in the human male reveals a hypothalamic site of estrogen feedback. J. Clin. Endocrinol. Metab. 85, 3027-3035.

21. Herbison A. E. (1998). Multimodal influence of estrogen upon gonadotropinreleasing hormone neurons. Endocr. Rev. 19, 302-330.

22. Horwitz K. B., Jackson T. A., Bain D. L., Richer J. K., Takimoto G. S. and Tung L. (1996) Nuclear receptor coactivators and corepressors. Mol Endocrinol 10, 1167 1177.

23. Kaufman J. M. (1996) The Neuroendocrine Regulation of Male Reproduction, in Male Infertility, vol. 1, F. H., Comhaire, ed., Chapman \& Hall Medical, London, pp. 29-54. 
24. Kerdelhué B., Brown S., Lenoir V., Queenan J. T. Jr., Jones G. S., Scholler R. and Jones H. W. Jr. (2002) Timing of Initiation of the Preovulatory Luteinizing Hormone Surge and Its Relationship with the Circadian Cortisol Rhythm in the Human. Neuroendocrinology 75, 158-163.

25. Kim B. H., Sung S. R., Choi E. H., Kim Y. I., Kim K. J., Dong S. H., Kim H. J., Chang Y. W., Lee J. I. and Chang R. (2000) Dedifferentiation of conditionally immortalized hepatocytes with long-term in vitro passage. Exp. Mol. Med. 32, 2937.

26. Knobil E. (1988) The neuroendocrine control of ovulation. Hum. Reprod. 3, 469472.

27. Lawson M. A., Li D., Glidewell-Kenney C. A. and Lopez F. J. (2001) Androgen responsiveness of the pituitary gonadotrope cell line LbetaT2. J. Endocrinol.170, 601-607.

28. Mangelsdorf D. J., Thummel C., Beato M., Herrlich P., Schutz G., Umesono K., Blumberg B., Kastner P., Mark M., Chambon P. and Evans R. M. (1995) The nuclear receptor superfamily: the second decade. Cell 83, 835-839.

29. McKenna N. J. and O'Malley B. W. (2002) Combinatorial control of gene expression by nuclear receptors and coregulators. Cell 108, 465-474.

30. Mellon P. L., Windle J. J. and Weiner R. I. (1991) Immortalization of neuroendocrine cells by targeted oncogenesis. Recent Prog. Horm. Res. 47, 6993

31. Moenter S. M., DeFazio R. A., Pitts G. R. and Nunemaker C. S. (2003) Mechanisms underlying episodic gonadotropin-releasing hormone secretion. Front. Neuroendocrinol. 24, 79-93. 
32. Nicol L., McNeilly J.R., Stridsberg M., Crawford J.L. and McNeilly A.S. (2002) Influence of steroids and $\mathrm{GnRH}$ on biosynthesis and secretion of secretogranin II and chromogranin A in relation to LH release in LbetaT2 gonadotroph cells. J. Endocrinol. 174, 473-483.

33. Nett T. M., Sawyer H. R. and Niswender G. D., Colorado AES Projects 20062007 (http://www.colostate.edu/dept/AES/projs/220.html)

34. Ortmann O., Johannsen K., Knuppen R. and Emons G. (1992a) Acute effects of oestradiol and progesterone on melittin- and gonadotrophin-releasing hormoneinduced LH secretion. J. Endocrinol. 132, 251-259.

35. Ortmann O., Tilse B. and Emons G. (1992b) Modulatory actions of estradiol and progesterone on phorbol ester-stimulated LH secretion from cultured rat pituitary cells. J. Steroid Biochem. Mol. Biol. 43, 619-627.

36. Pasqualini C., Guivarc'h D., Boxberg Y. Nothias F., Vincent JD and Vernier P. (1999) Stage- and region-specific expression of estrogen receptor $\alpha$ isoforms during ontogeny of the pituitary gland. Endocrinology 140, 2781-2789.

37. Pasqualini C., Guivarc'h D., Barnier J. V., Guibert B., Vincent J. D. \& Vernier P. (2001) Differential subcellular distribution and transcriptional activity of $\Sigma E 3, \Sigma E 4$, and $\Sigma E 3-4$ isoforms of the rat estrogen receptor-a. Molecular Endocrinology 15, 894-908.

38. Rasmussen T. H. and Nielsen J. B. (2002) Critical parameters in the MCF-7 cell proliferation bioassay (E-Screen). Biomarkers 7, 322-336.

39. Resnick E. M., Schreihofer D. A., Periasamy A. and Shupnik M. A. (2000) Truncated Estrogen Receptor Product-1 Suppresses Estrogen Receptor Transactivation by Dimerization with Estrogen Receptors alpha and beta. J. Biol. Chem. 275, 7158-7166. 
40. Rosenberg S. B. and Mellon P. L. (2002) An Otx-related homeodomain protein binds an LHbeta promoter element important for activation during gonadotrope maturation. Mol. Endocrinol. 16, 1280-1298.

41. Schreihofer D. A., Stoler M. H. and Shupnik M. A. (2000) Differential expression and regulation of estrogen receptors (ERs) in rat pituitary and cell lines: estrogen decreases ERalpha protein and estrogen responsiveness. Endocrinology 141, 2174-2184.

42. Swope D, Harrell JC, Mahato D, Korach KS (2002) Genomic structure and identification of a truncated variant message of the mouse estrogen receptor alpha gene. Gene 294:239-247.

43. Thomas P., Mellon P. L., Turgeon J. and Waring D. W. (1996) The L beta T2 clonal gonadotrope: a model for single cell studies of endocrine cell secretion. Endocrinology 137, 2979-2989.

44. Tilbrook A. J. and Clarke I. J. (2001) Negative feedback regulation of the secretion and actions of gonadotropin-releasing hormone in males. Biol. Reprod. $64,735-742$.

45. Turgeon J. L., Kimura Y., Waring D. W. and Mellon P. L. (1996) Steroid and pulsatile gonadotropin-releasing hormone $(\mathrm{GnRH})$ regulation of luteinizing hormone and $\mathrm{GnRH}$ receptor in a novel go nadotrope cell line. Mol. Endocrinol. $10,439-450$.

46. Turgeon J. L. and Waring D. W. (2006) Differential expression and regulation of progesterone receptor isoforms in rat and mouse pituitary cells and L $\beta T 2$ gonadotropes. J. Endocrinol. 190, 837-846.

47. Wang C. (1988) Bioassays of follicle stimulating hormone. Endocr. Rev. 9, 374377. 
48. Waring D. W. and Turgeon J. L. 1980. Luteinizing hormone-releasing hormoneinduced luteinizing hormone secretion in vitro: cyclic changes in responsiveness and self-priming. Endocrinology 106, 1430-1436.

49. Wildt L., Hausler A., Marshall G., Hutchison J. S., Plant T. M., Belchetz P. E. and Knobil E. (1981) Frequency and amplitude of gonadotropin-releasing hormone stimulation and gonadotropin secretion in the rhesus monkey. Endocrinology $109,376-385$.

50. Yamada Y., Yamamoto H., Yonehara T., Kanasaki H., Nakanishi H. Miyamoto E. and Miyazaki K. (2004) Differential activation of the luteinizing hormone betasubunit promoter by activin and gonadotropin-releasing hormone: a role for the mitogen-activated protein kinase signaling pathway in LbetaT2 gonadotrophs. Biol. Reprod. 70, 236-243. 
Figure 1A

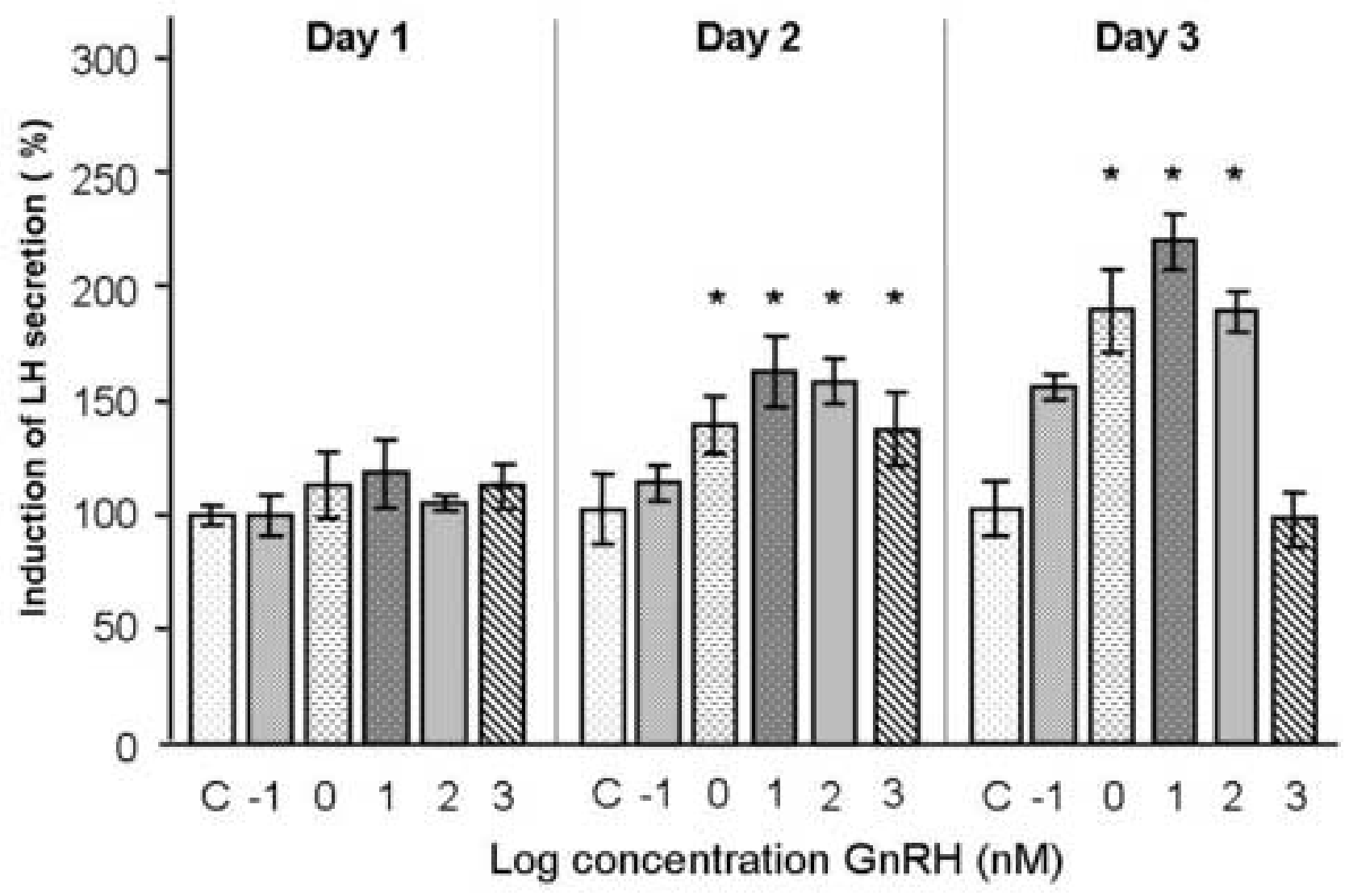


Figure 1B

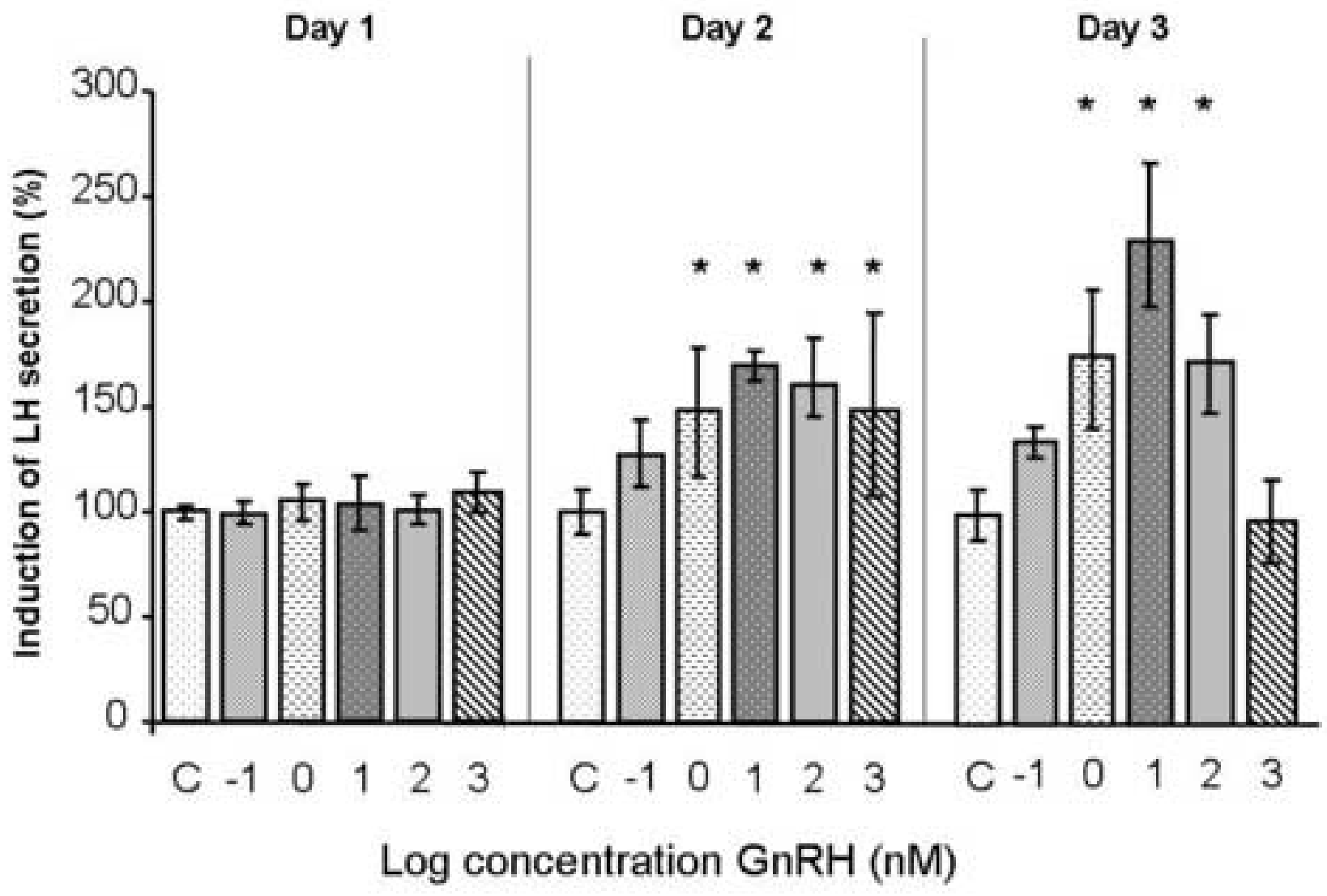


Figure 2

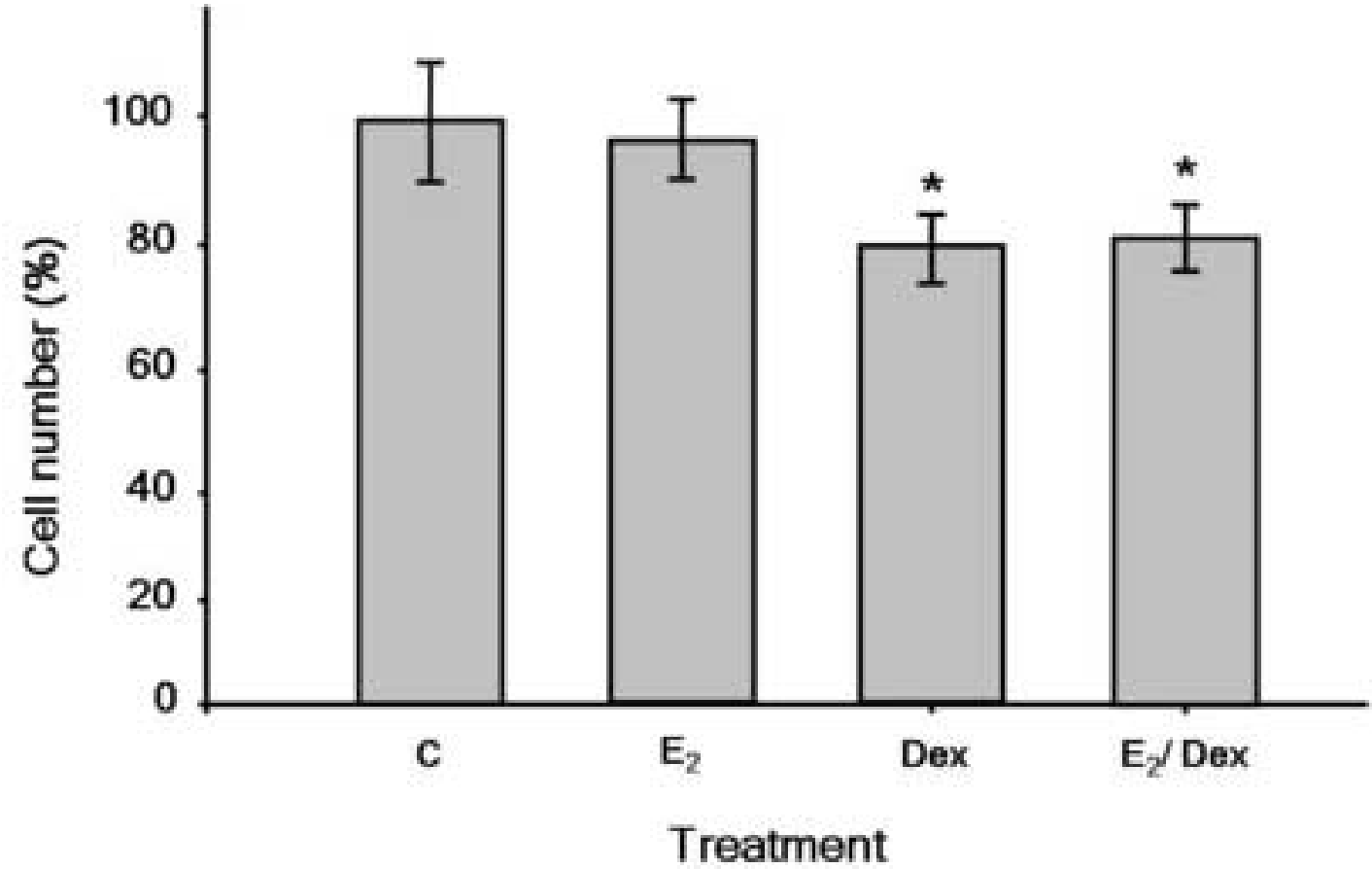


Figure 3

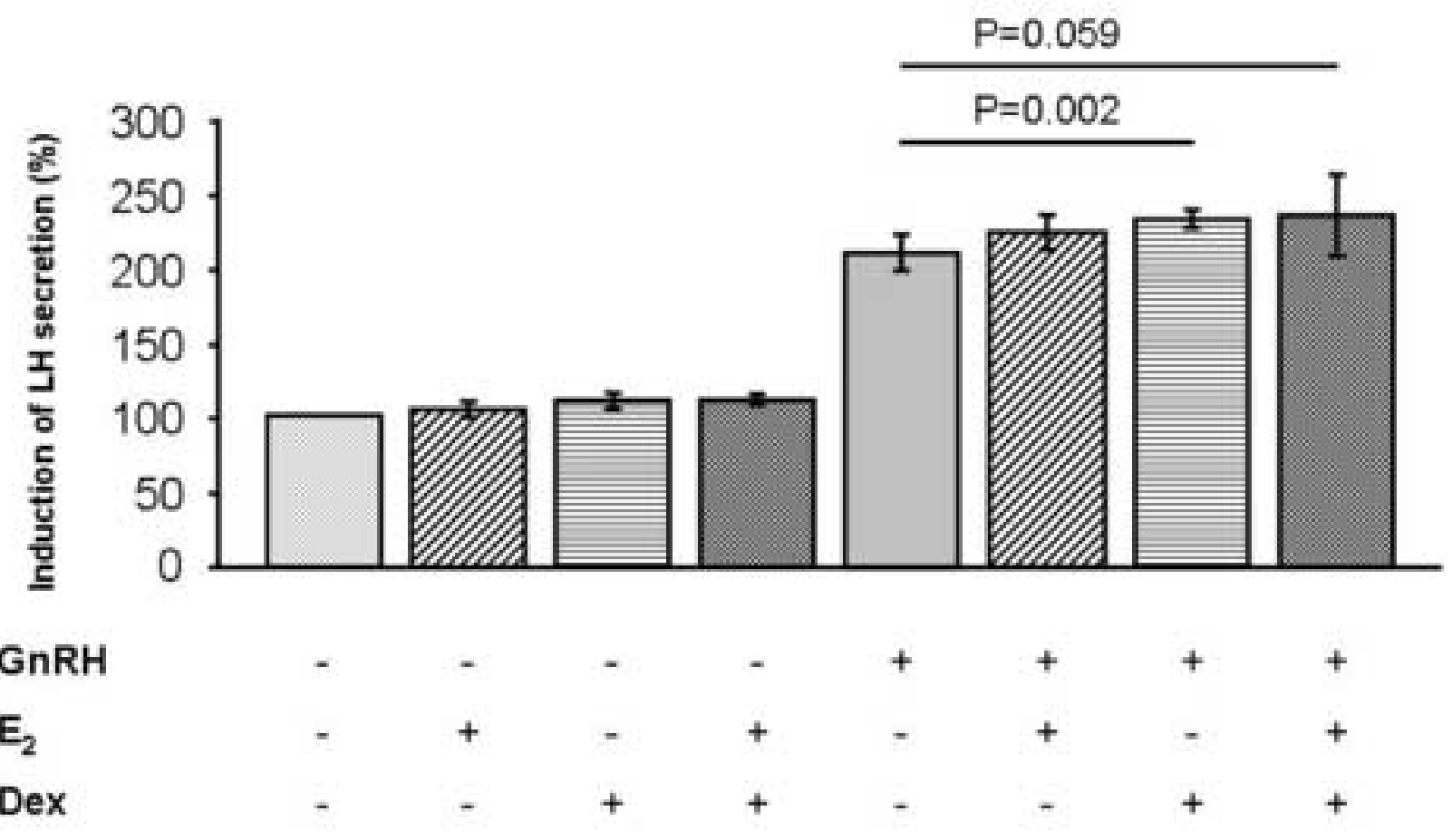


Figure 4

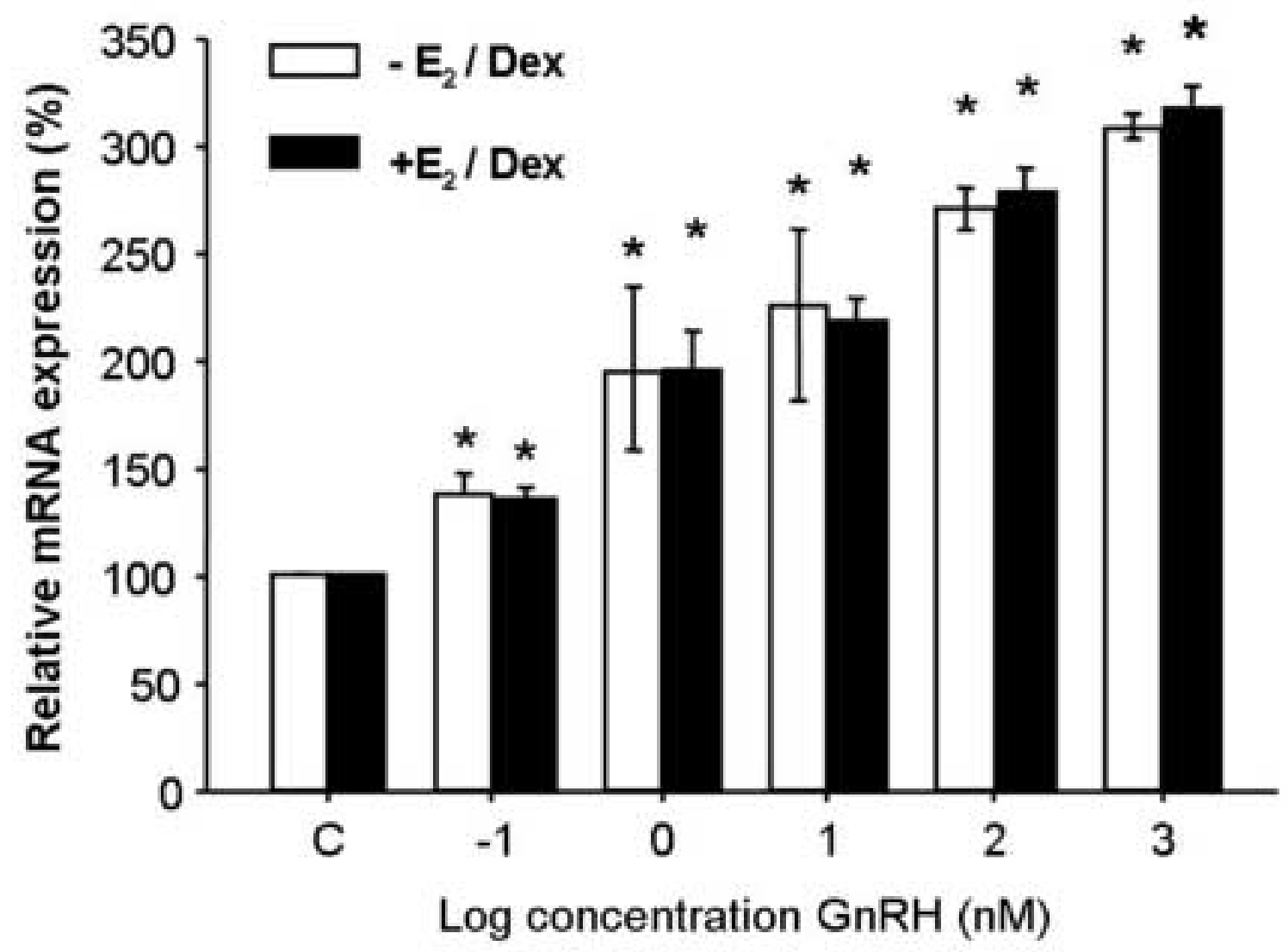


Figure 5

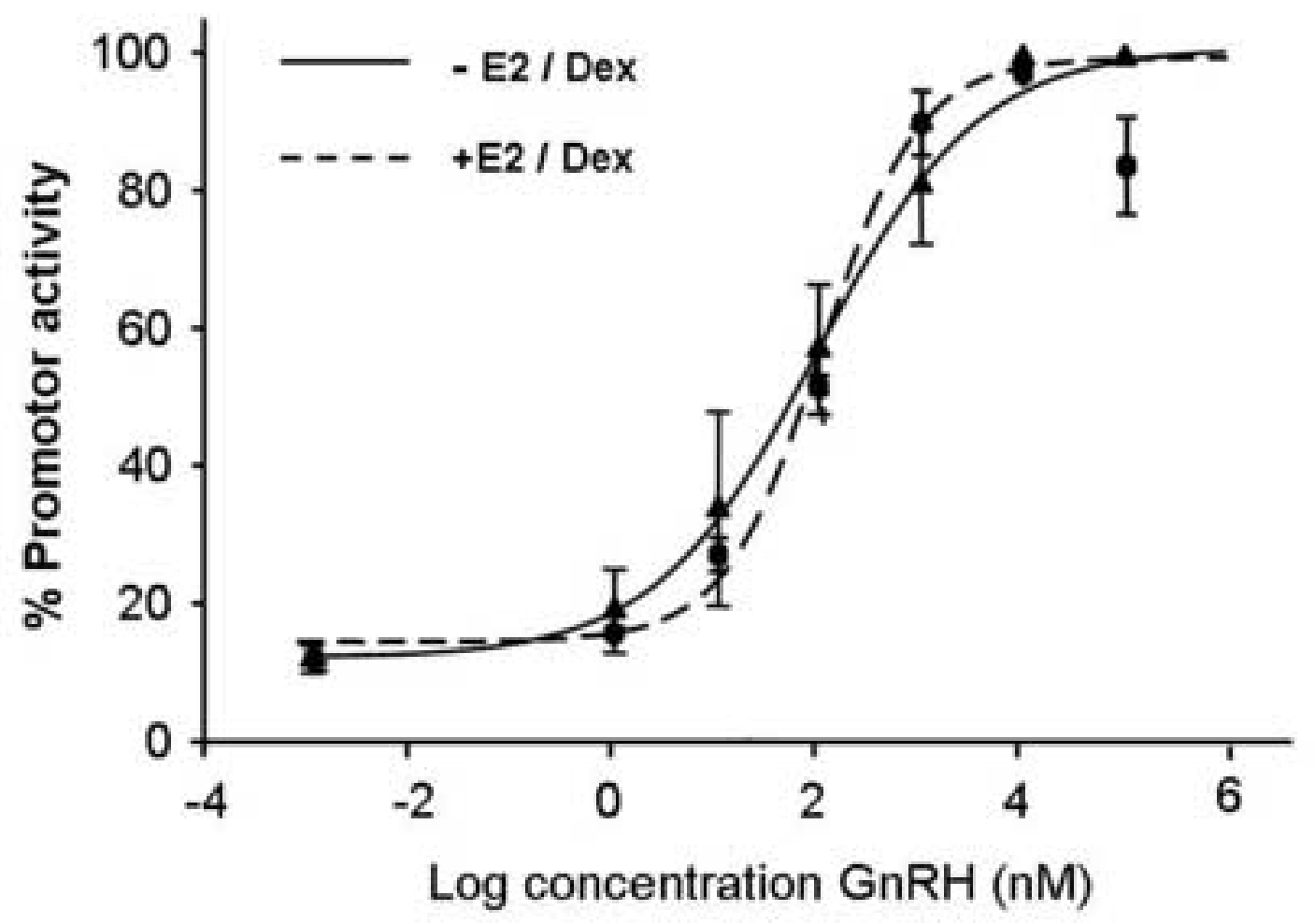


Figure $6 \mathrm{~A}$

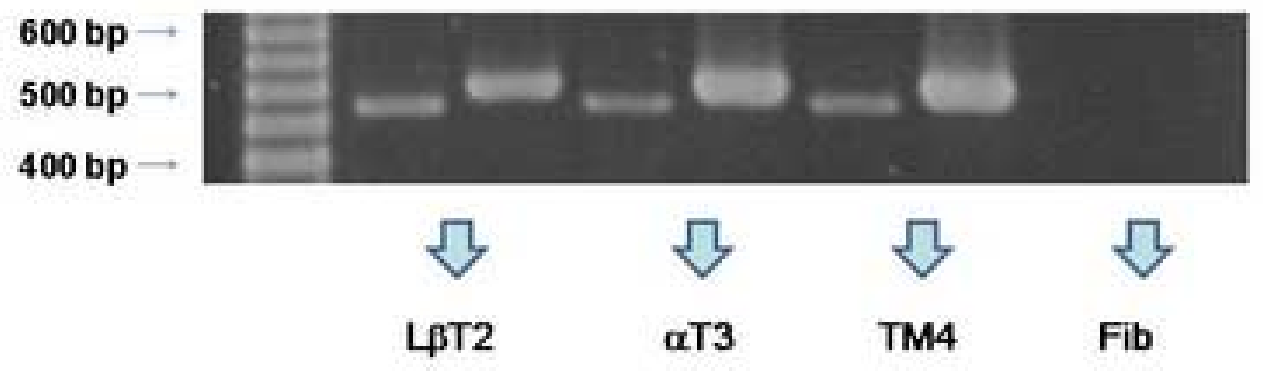

Figure 6B

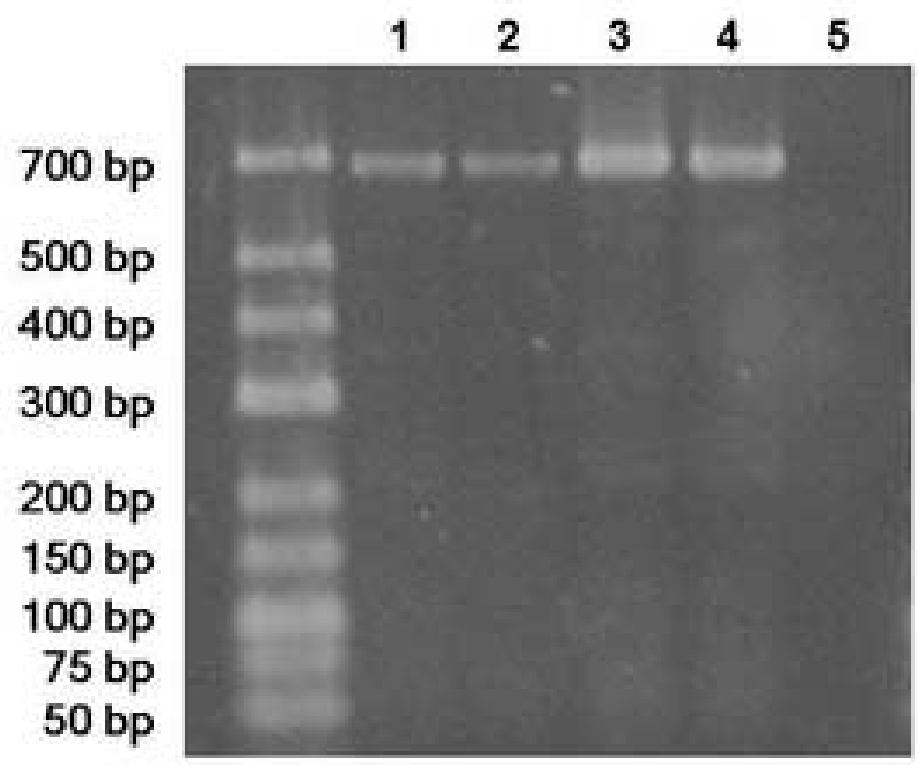


Figure 7

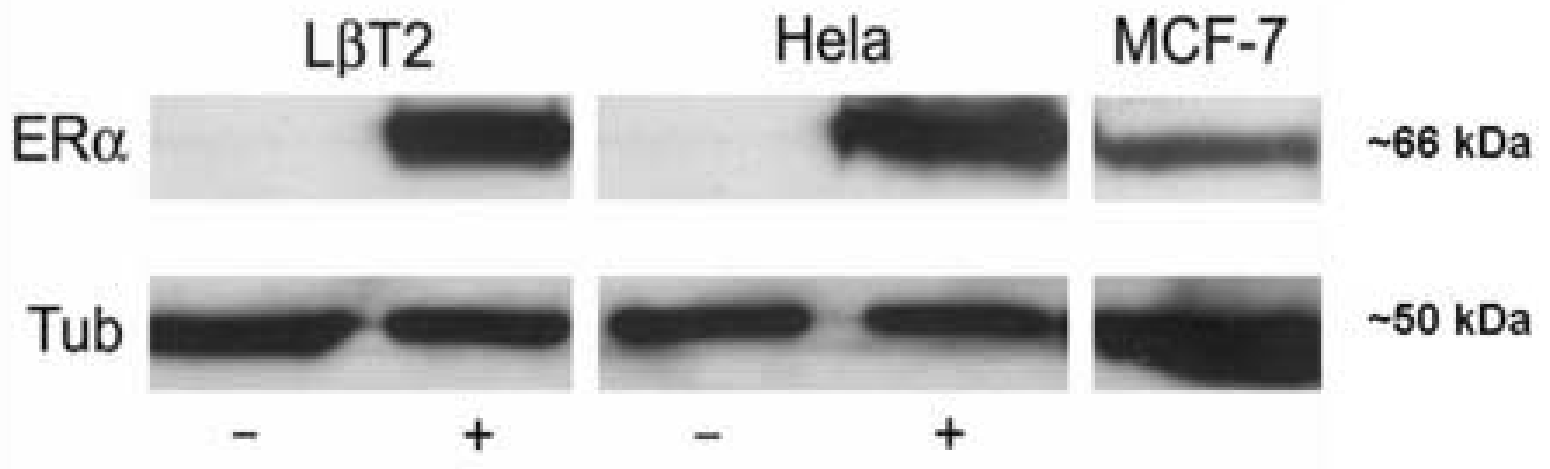


Figure 8

Hela

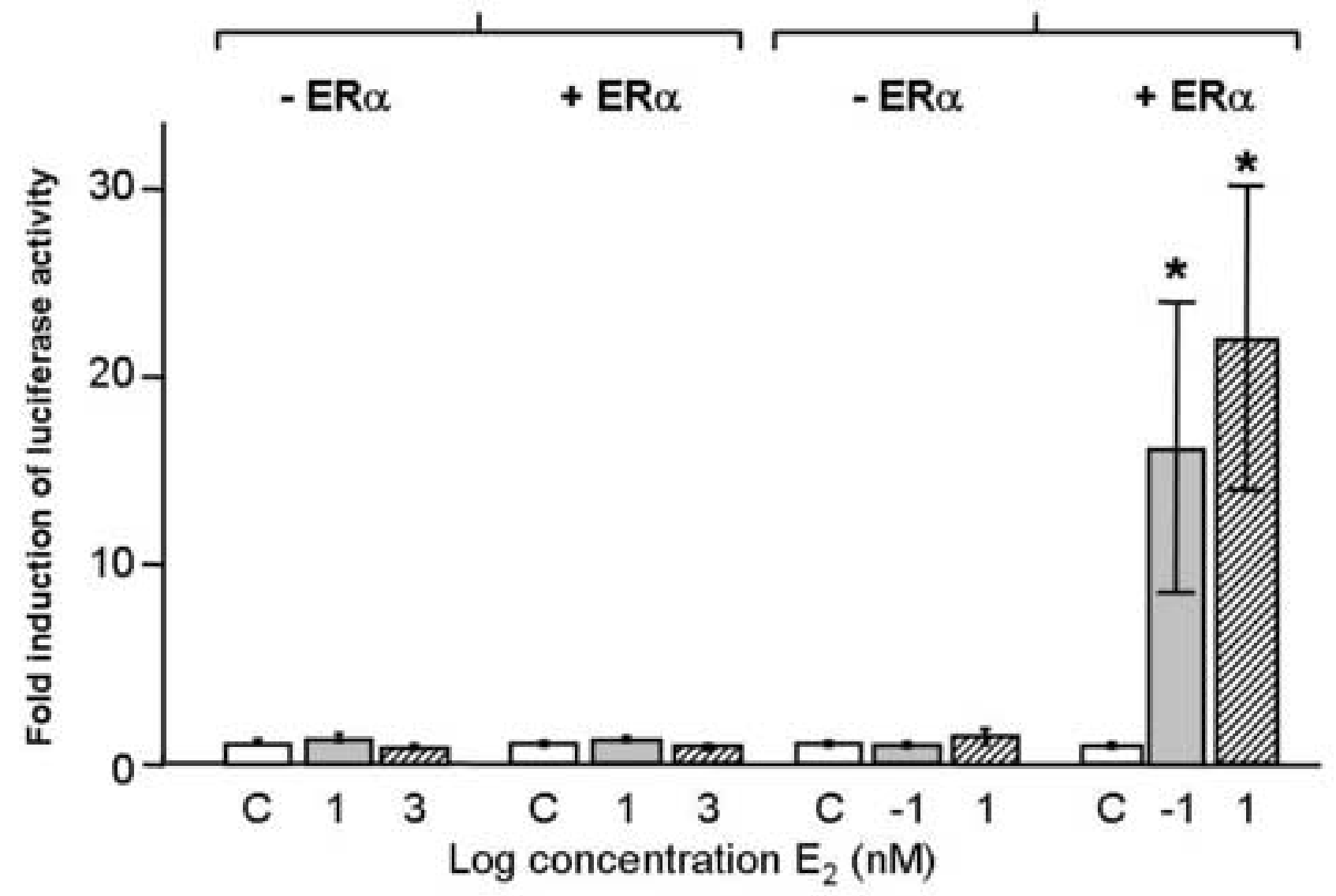


Figure 9
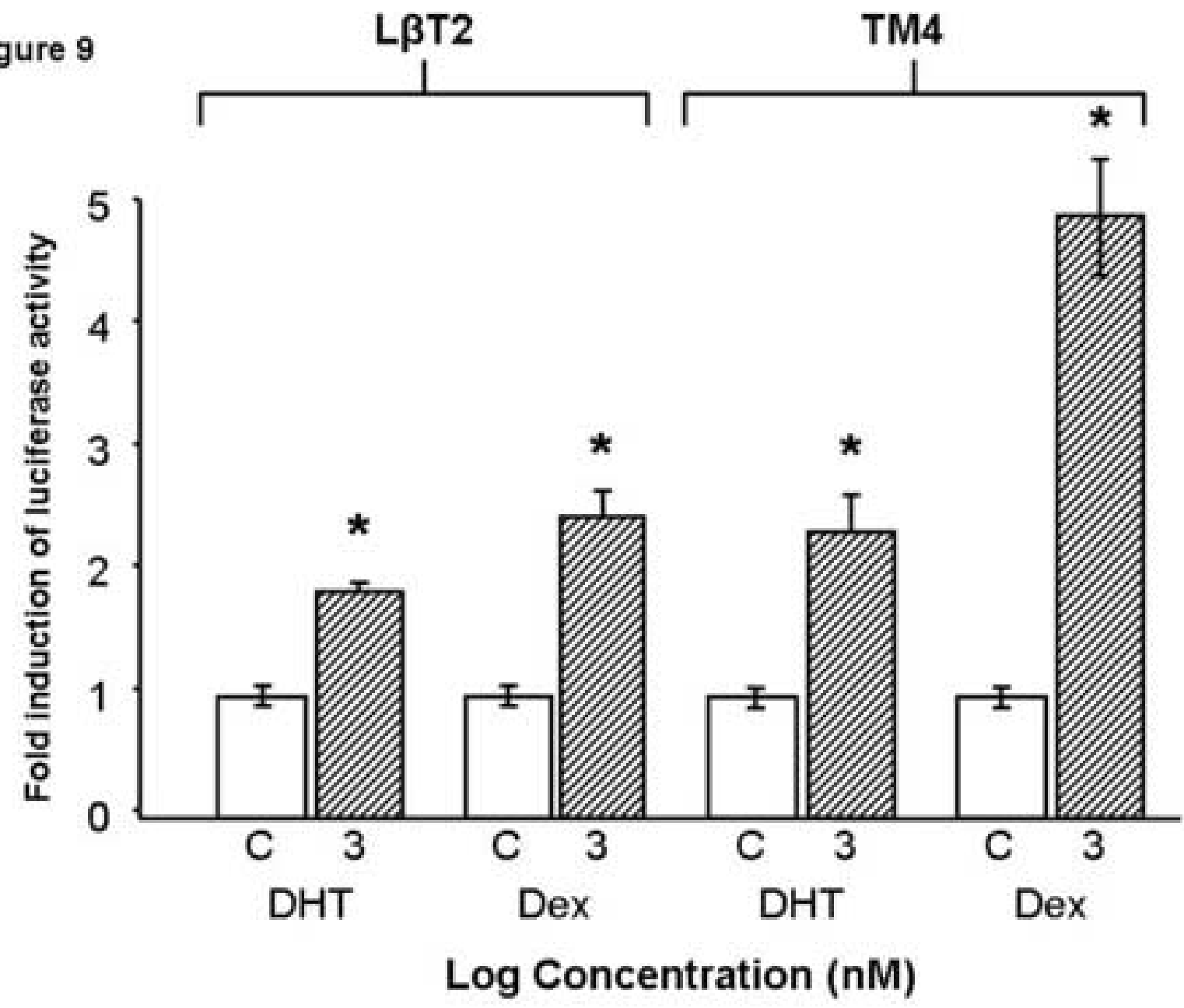

Page 38 of 42 


\section{Legends}

\section{Figure 1:}

Gonadotropin-releasing hormone (GnRH)-induced luteinizing hormone (LH)secretion in the L $\beta T 2$ cell line.

L $\beta$ T2 cells were exposed daily to $\mathrm{GnRH}(0.1-1000 \mathrm{nM})$ during three consecutive days using a short pulse setup (Fig. 1A; 15 min GnRH - 75 min collection of GnRH-free medium) or a $4 \mathrm{~h}$ exposure setup (Fig. 1B). Values for treated cells were corrected for cell number and are expressed relative to vehicle control (experimental medium containing $0.1 \%$ ethanol), set at $100 \%$. Results are presented as the mean \pm SD from three separate experiments. ${ }^{*}=P<0.05$ versus vehicle control $(\mathrm{C})$.

\section{Figure 2:}

Effect of $E_{2}(0.2 \mathrm{nM})$ and/ or Dex $(20 \mathrm{nM})$ treatment on cell proliferation in the L $\beta$ T2 cell line.

At the end of the LH secretion experiments (third day of repeated exposure to $\mathrm{GnRH}$ ), cell number was determined using the trypan blue exclusion method. Results were expressed relative to vehicle control (C), set at $100 \%$. Results are presented as the mean \pm SD from three separate experiments. ${ }^{*}=P<0.05$ versus vehicle control $(\mathrm{C})$.

\section{Figure 3:}

Effects of different steroid treatments on LH secretion following repeated exposure to $10 \mathrm{nM}$ of $\mathrm{GnRH}$.

L $\beta$ T2 cells were exposed daily to $10 \mathrm{nM}$ of $\mathrm{GnRH}$ during three consecutive days using a short pulse setup (15 min $\mathrm{GnRH}-75$ min collection of $\mathrm{GnRH}$-free medium) in the absence or presence of $0.2 \mathrm{nM} \mathrm{E}_{2}$ and $20 \mathrm{nM}$ Dex, alone or combined. At treatment day 
3, LH medium concentrations were determined and corrected for cell number. Shown are also controls (in absence of $\mathrm{GnRH}$ ). Values are expressed relative to vehicle control (experimental medium containing $0.1 \%$ ethanol), set at $100 \%$. Results are presented as the mean \pm SD from three separate experiments. ${ }^{*}=P<0.05$ versus vehicle control.

\section{Figure 4:}

\section{Dose-dependent stimulation of rat LH $\beta$-subunit (LH $\beta$-su) mRNA expression by GnRH in the L $\beta T 2$ cells.}

L $\beta$ T2 cells were exposed daily to $\mathrm{GnRH}(0.1-1000 \mathrm{nM})$, alone or in the presence of $E_{2}$ $(0.2 \mathrm{nM})$ and Dex (20 nM) during three consecutive days. At the final day, L $\beta T 2$ cells were harvested and total RNA was extracted for real-time PCR analysis. Values for treated cells are expressed relative to their respective control (experimental medium containing $0.1 \%$ ethanol and experimental medium supplemented with $E_{2}(0.2 \mathrm{nM})$ and Dex (20 $\mathrm{nM})$ respectively), set at $100 \%$. Results are presented as the mean \pm SD from three separate experiments. ${ }^{*}=P<0.05$ versus respective control $(\mathrm{C}) ; \mathrm{GnRH}$-induced LHß-su mRNA expression was not significantly altered following treatment $E_{2} /$ Dextreatment.

\section{Figure 5:}

\section{Modulation of rLH $\beta$-su promoter activity by $\mathrm{GnRH}$.}

L $\beta T 2$ cells were transiently transfected with the $\mathrm{rLH} \beta$-Luc construct ( $250 \mathrm{ng}$ ), which consists of an 1800 bp fragment of the 5' flanking region of the rLH $\beta$-su gene, coupled to a gene encoding for the luciferase enzyme. L $\beta T 2$ cells were exposed to $\mathrm{GnRH}(0.1$ $10000 \mathrm{nM}$ ), alone (full line) or in combination (dashed line) with $\mathrm{E}_{2}(0.2 \mathrm{nM})$ and Dex (20 $\mathrm{nM})$ for $16 \mathrm{~h}$. Results are presented as the mean \pm SD from three separate transfections. 
Figure 6:

\title{
Reverse-transcription PCR analysis of ER expression in the L $\beta T 2$ cell line.
}

Fig. 6A: The expression of ER $\alpha$ and an alternative splice variant was investigated using reverse transcriptase polymerase chain technique (RT-PCR). Full length ERa and the alternative message correspond to an amplicon of $516 \mathrm{bp}$ and $480 \mathrm{bp}$, respectively. The estrogen-responsive TM4 Sertoli cell line and the gonadotropic $\alpha \mathrm{T} 3-1$ cell line served as a positive control, while lung fibroblasts were used as an alleged negative control. Fig. 6B: RT-PCR was applied to analyze the expression of alternative ERa mRNA splicing variants, which contains an exon 3 and/ or exon 4 deletion. Full length ERa mRNA corresponds to a 702 bp amplicon. Sample 1 and 2 represent two different RNA extracts of the LBT2 cell line. Sample 3 and 4 correspond to the $\alpha$ T3-1 and TM4 cell lines, respectively. Murine, lung fibroblast RNA (lane 5) served as an alleged negative control.

Figure 7:

Western Blot analysis of ER $\alpha$ expression in the L $\beta T 2$ and the Hela cell line. Lysates were prepared from LßT2 and Hela cells, witho ut (-) and with (+) prior transfection with a human ER $\alpha$ expression vector, and analyzed for the presence of ER $\alpha$ protein (66 kDa fragment). The human MCF-7 cell line served as a positive control. Mouse tubulin (Tub.; $50 \mathrm{kDa}$ fragment) was used as loading control.

Figure 8:

\author{
Assessment of estrogen receptor (ER)-mediated gene transcription in the L $\beta$ T2 \\ and the Hela cell line. \\ L $\beta$ T2 and Hela cells were transiently transfected with the ERE-tk-Luc construct alone, or \\ in combination with a human ERa expression vector. The ERE-tk-Luc reporter plasmid \\ consists of two copies of the Xenopus laevis vitellogenin A2 ERE (58-
}

GGTCACAGTGACC-38), linked to the thymidine kinase (tk) promoter and coupled to a 
gene encoding for the luciferase enzyme. Cells were exposed to $E_{2}(10 n M$ and $1000 n M$ for L $\beta$ T2 cells; 0.1 and $10 \mathrm{nM}$ for Hela cells) for $16 \mathrm{~h}$. Results are presented as the mean $\pm \mathrm{SD}$ from three separate transfections. ${ }^{*}=P<0.05$ versus vehicle control (C).

\section{Figure 9:}

\section{Differential response of the MMTV-promoter in the L $\beta T 2$ and TM4 cell lines.}

Both cell lines were transiently transfected with the AR- and GR-driven MMTV-Luc reporter plasmid and treated with $\operatorname{Dex}(1 \mu \mathrm{M})$ or dihydrotestosterone $(\mathrm{DHT} ; 1 \mu \mathrm{M})$ for 16h. Results are presented as the mean \pm SD from three separate transfections. ${ }^{*}=P<$ 0.05 versus vehicle control(C). 